\title{
Northern food networks: Building collaborative efforts for food security in remote Canadian Aboriginal communities
}

\author{
Rebecca Schiff ${ }^{a} *$ and Fern Brunger ${ }^{a}$ \\ Memorial University of Newfoundland
}

\begin{abstract}
Submitted January 31, 2013 / Revised April 9 and May 10, 2013 / Accepted May 17, 2013 /
Published online June 21, 2013

Citation: Schiff, R., \& Brunger, F. (2013). Northern food networks: Building collaborative efforts for food security in remote Canadian Aboriginal communities. Journal of Agriculture, Food Systems, and Community Development, 3(3), 31-45 . http://dx.doi.org/10.5304/jafscd.2013.033.012
\end{abstract}

Copyright (C) 2013 by New Leaf Associates, Inc.

\begin{abstract}
Canada's northern and remote regions experience high rates of food insecurity, exceptionally high food costs, environmental concerns related to contamination and climate change, and a diversity of other uniquely northern challenges related to food production, acquisition, and consumption. As such, there is a need to understand and develop strategies to address food-related concerns in the North. The diversity of communities across the North demands the tailoring of specific, local-level responses to meet diverse needs. Over the past

${ }^{a}$ Division of Community Health and Humanities, Faculty of Medicine, Memorial University of Newfoundland

* Corresponding author: Rebecca Schiff, Division of Community Health and Humanities, Faculty of Medicine, Memorial University of Newfoundland, Labrador Institute, P.O. Box 490 Stn B, Happy Valley_Goose Bay, NL A0P 1E0 Canada; +1-709-896-6212; rschiff@mun.ca
\end{abstract}

decade, local networks have emerged as a powerful method for developing localized responses, promoting food security and the development of more sustainable food systems across Canada and North America. Despite this, there is a paucity of research examining challenges and effective approaches utilized by these local networks or their potential applicability for building food security in rural, remote, and northern communities. This research utilized participant observation as a method to examine the experiences of a Northern Canadian food security network. The experience of this network points to strategies that can lead to successful collaborative approaches aimed at implementing programs to address food security in northern and remote communities.

\section{Keywords}

collaboration, community food assessment, industrial development, network, northern, remote 


\section{Introduction}

Canada's northern and remote regions experience high rates of food insecurity, exceptionally high food costs, environmental concerns related to contamination and climate change, and a diversity of other uniquely northern food-related challenges. The diversity of communities across the North demands the tailoring of specific, local-level responses to meet diverse needs. Over the past decade, local networks have emerged as a powerful method for developing localized responses and promoting food security and the development of more sustainable food systems across Canada and North America. Despite this, there is a paucity of research examining challenges and effective approaches utilized by these local networks or their potential applicability for building food security in rural, remote, and northern communities. This article examines the experiences of a Northern Canadian food security network in an attempt to understand strategies that can lead to successful collaborative approaches to address food security in northern and remote communities. ${ }^{1}$

To contextualize the unique experiences of remote communities, we begin this article with an examination of existing evidence of food security issues in Northern Canada. This leads to examination of a community-led food assessment (CLFA) process ${ }^{2}$ utilized in a northern community to assess food security concerns and create an action plan. We then describe the application of nonethnographic participant observation as a method to examine the approach utilized by a Northern

\footnotetext{
${ }^{1}$ For the purpose of this research we define success of a food network or coalition as the accomplishment of tasks and goals which the collaborative has set for itself

2 The Community Food Security Coalition (n.d.) defined the basic concept of a "community food assessment" as "a participatory and collaborative process that examines a broad range of food-related issues and resources in order to inform actions to improve the community's food system." (Community Food Security Coalition, 2012). In Canada, several provincial level initiatives, including the Food Security Network of Newfoundland and Labrador, elaborated on this concept to define community-led food assessments as community food assessments that are primarily designed, implemented, and authored ("led") by residents of the community.
}

Canadian food security network to implement the action plan defined in the CLFA process. The experience of this network points to strategies that might lead to successful collaborative approaches aimed at implementing programs to address food security in northern and remote communities.

\section{Food Security in Northern Canada ${ }^{3}$}

Northern and remote Aboriginal communities in Canada experience numerous unique factors limiting their ability to achieve food security. Many northern communities utilize a combination of store-bought foods, foods grown within or near communities, and "country foods" to meet nutritional needs (Ferguson, 2011). Limiting factors on food security are related to all of these food acquisition methods.

Long-distance transportation to remote areas has a significant impact on the availability, quality, and cost of store-bought foods. Fuel and other costs associated with food transportation contribute to food costs that are significantly higher than those found in Canada's urban centers (Aboriginal and Northern Affairs Canada, 2008; Boult, 2004; Myers, Powell, \& Duhaime, 2004). While food costs are higher in all of these communities when compared to their southern counterparts, costs in less accessible northern communities are even higher than costs in northern "service centers." Increased food costs are not consistent across the North such that more remote communities (such as Old Crow and Pangnirtung) experience much higher costs than those found in remote service centers such as Yellowknife, Inuvik, and Happy Valley-Goose Bay. ${ }^{5}$ Issues related to the high costs of retail foods are further complicated for the significant number of low-income households who

\footnotetext{
${ }^{3}$ For the purposes of this research we define "Northern Canada" according to Statistics Canada's delineation of the North; see (McNiven \& Puderer, 2000).

${ }^{4}$ Many northern, rural, and remote communities use the term "country food" to refer to foods acquired through hunting, fishing, and gathering.

${ }^{5}$ Examination of the data provided by Aboriginal and Northern Affairs Canada indicates a trend when comparing "service centers" with smaller and more isolated communities; see (Aboriginal and Northern Affairs Canada, 2008).
} 
face additional economic pressures in accessing healthy foods in the North (Boult, 2004; Myers et al., 2004).

In addition to the high cost of food, quality and availability are also concerns (Boult, 2004; Myers, et al., 2004). A survey of food quality and availability conducted in Labrador in 2001 revealed significant concerns related to the quality of perishable foods found in local stores (Ladouceur \& Hill, 2001). Ladouceur and Hill (2001) indicate that 80\% of respondents also reported poor availability, indicating that there was never or only sometimes enough variety of fresh fruits and vegetables available for purchase. Additional cultural and socioeconomic factors complicate issues of cost and availability. These include knowledge about how to prepare different foods, a limited range of choices for different foods, and the ability to prepare and consume healthy foods (Beaumier \& Ford, 2010; Myers, et al., 2004).

A variety of factors limit the ability to produce or acquire food through gardening, farming, and fishing in northern communities. Short to nonexistent growing seasons, light levels, permafrost, and poor soil quality impact the capacity to grow food (Jóhannesson, 2012; Juday et al., 2010; Leahey, 1954). Some communities experience difficulty in accessing safe water for irrigation due to a variety of issues such as the impact of industrial development, mining, and hydroelectric projects on water quality (Airhart, Janes, \& Jamieson, 2011; Jóhannesson, 2012; Myers, et al., 2004; Thompson, 2005). Access to agricultural and fishing supplies is also limited, in terms of cost and selection, due to transportation issues which are similar to those that impact the cost and availability of store-bought foods (Airhart, et al., 2011; Jóhannesson, 2012)

The ability to access country foods is also coming under increased pressure. Traditional food access provides significant nutritional and social benefits (Boult, 2004; Chan et al., 2006; J. Ford et al., 2007; J. D. Ford, Pearce, Duerden, Furgal, \& Smit, 2010; Myers, et al., 2004; Thompson, 2005). Impacts of climate change and environmental pollutants are affecting plants and wildlife as well as access to traditional hunting, gathering, and fishing grounds (Boult, 2004; Meakins \& Kurvits, 2009; Myers, et al., 2004; Thompson, 2005). Socio- economic issues also affect access to country foods due to challenges such as the: costs of hunting, fishing, gathering supplies; ability to adapt work and school hours to seasonal harvesting periods; and loss of traditional knowledge about acquiring and preparing country foods (Boult, 2004; Chan, et al., 2006; Myers, et al., 2004).

Store-bought, "locally" produced, and country foods are the three main sources of food for northern communities. However, due to interrelated cost, quality, and availability barriers, northern communities do not have adequate access to these primary food sources. Despite the interrelationships, there has been fairly little examination of northern food issues from a "food systems" perspective. ${ }^{6}$ A few examples of northern food systems studies are beginning to emerge. However, there exists little in terms of studies that document collaborative approaches used to formulate and implement food systems approaches in the North. With the exception of a handful of articles in the scholarly literature, there is also a paucity of information on local-level food collaboratives in general, or in the varied forms of food coalitions, networks, councils, or committees.

\section{Addressing the Delivery of Essential Services through Collaborative System-level Governance}

As a basic and essential human need, access to healthy, affordable food is critical to creating healthy and sustainable communities in the North. However, government oversight of food-related issues is often fragmented, having little cohesive oversight at municipal, regional, and provincial levels.

An examination of food-related governance structures provides some insight into issues of fragmentation. Today when we think of food production and consumption we are assailed by a multitude of industries. We have food production with separate agriculture and fishery sectors, food industry with a multitude of processing and packaging sectors, food sales with marketing, retail,

\footnotetext{
6 "Food systems" perspectives are defined as approaches that recognize the interrelatedeness of all aspects of food issues.
} 
wholesale, and hospitality sectors, and finally waste-management sectors that deal with disposal or recycling of food wastes. There are sectors that each deal separately with labor, the various types of agriculture (fruit, vegetables, grains, dairy), food transportation, food safety, food culture (food TV, food magazines, food websites), school food, and diet-related health issues. Understanding the connections among all of these sectors has become a complex and daunting task.

Added to this breakdown, division, and separation of food activities is the fragmentation of the political and decision-making structures surrounding food issues. This fragmentation is apparent when we look at the number of regulatory institutions made solely and independently responsible for different food-related activities. There are departments of agriculture, trade, waste management, labor, communications, tourism, transportation, and health, to name a few. All of the various food-related government and industry bodies create policy and regulations to govern their own sectors of these critical systems.

Fragmented governance and industry oversight creates policy vacuums, where the absence of collaborative planning for food leaves gaps, duplication, and inadequacies in decision-making processes (Pothukuchi \& Kaufman, 1999, 2000). This occurs among decision-making bodies at all geopolitical levels: municipal, regional, state (or provincial), federal, and international. For communities in Canada's north, inadequate funding and capacity at municipal levels to plan for and coordinate food services exacerbates the situation.

What becomes apparent is that, despite the significance of food to healthy development in Canada's north, current governance structures are not able to provide coordinated oversight for growth, changing needs, and circumstances. As such, there is a need to develop collaborative governance structures that can provide flexibility to adapt to the changing needs and circumstances of diverse and rapidly changing northern communities.

There is some promising evidence to suggest that collaborative, systems-level approaches, in the form of food councils, networks, and coalitions, can help to facilitate the development of healthy food systems (Dahlberg, 1994; Dahlberg, Clancy, Wilson, O’Donnell, \& Hemingway, 1997; Harper, Shattuck, Holt-Giménez, Alkon, \& Lambrick, 2009; McNiven \& Puderer, 2000; Schiff, 2007; Yeatman, 1994, 1997, 2003). The applicability, however, of such approaches in northern or remote communities remains largely unexplored. This research examines the experiences of a food security network in Happy Valley-Goose Bay, a remote community in Central Labrador. This network employed a food systems perspective to develop a community food assessment and implement its recommendations. The experiences of Happy Valley-Goose Bay illustrate the nature of food security-related stress in northern and remote communities. This paper aims to analyze the strategies that were used to develop community-based collaborative approaches to reduce food insecurity, as well as programs implemented to address the identified priorities.

\section{Research approach and methodology}

This research utilized non-ethnographic participant observation as a primary method. Participant observation is a valuable approach when a researcher is interested in gaining access to a "backstage culture" (DeMunck \& Sobo, 1998, p. 43). Kawulich (2005) explains five reasons for use of participant observation, as described in LeCompte and Schensul (2010, p. 91):

- to identify and guide relationships with informants;

- to help the researcher get the feel for how things are organized and prioritized, how people interrelate, and what are the cultural parameters;

- to show the researcher what the cultural members deem to be important in manners, leadership, politics, social interaction, and taboos;

- to help the researcher become known to the cultural members, thereby easing facilitation of the research process; and

- to provide the researcher with a source of questions to be addressed with participants. 
Use of participant observation as a research method, according to those rationales, allows researchers a closer and more in-depth understanding of group dynamics. For that reason, and in the case of non-ethnographic applications, this method is particularly favored in organizational research (Iacono, Brown, \& Holtham, 2009). Iancono et al. (2009) indicate that "sometimes participant observation arises from an ongoing work situation" (p. 42) as was the situation with our research. The researchers were members of this particular food network prior to and following this research. This situation is not uncommon in participant observation research. Iancono et al. (2009) describe typical situations and the value of this methodology in such situations in which members of organizations:

are called upon to manage problematic situations characterised by indeterminacy, uniqueness and instability. Schon (1991, quoting Ackoff, 1979) appropriately terms such situations 'messes.' The best professionals are able to make sense of these 'messes,' discern patterns, identify deviations from a norm, recognise phenomena and adjust their performance. Such processes may be intuitive, tacit, unconscious. The author terms this 'reflection-in-action.' (p.42)

As such, this paper presents a "reflection-inaction" arising out of a year of participant observation with a food network in a northern, remote community. The food network is an unincorporated organization that was formed during a CLFA process. Membership includes representatives of a variety of sectors (such as housing, health, and education) as well as members of the general public who are interested in food security issues. ${ }^{7}$ Dr.

\footnotetext{
${ }^{7}$ The network is not incorporated and has no legal structure and (at the time of writing this article) had no formal relationships with any incorporated organizations. The network identifies a project and a potential funding source, then identifies an organization with which to partner in a funding application. The partner organization holds the funding, but the network directs how the funding is used. For example, funding for the network coordinator position is
}

Schiff is part of this informal network as a community activist and academic engaged in food security concerns through project-based activism.

Dr. Schiff, a long-time food security activist, became involved with the network when she moved to the region, shortly after the CLFA process and report were completed. The importance of research on the innovative and important work of the network was immediately obvious. With the knowledge and support of fellow network members, Dr. Schiff began the participant observation research early on during her engagement with the network. Dr. Brunger, an anthropologist and experienced participant-observation researcher working with communities in the area, was brought in to contribute to the research by explicitly engaging Dr. Schiff in self-reflective scrutiny of the work of the network and of her dual role as community member/activist and researcher.

Methodologically this research engages the community in participatory action research, but in this case, the community engagement preceded the intent to conduct research. Research Ethics Board (REB) review was not required for this participant observation research, and in keeping with the 2nd edition of the Tri-Council Policy Statement: Ethical Conduct for Research Involving Humans (TCPS 2) (Canadian Institutes of Health Research, Natural Sciences and Engineering Research Council of Canada, and Social Sciences and Humanities Research Council of Canada , 2010), Canadian Institutes of Health Research (CIHR) (2008), and National Aboriginal Health Organisation (NAHO) (2003) guidelines, Aboriginal community consent was not sought, as the research was not conducted specifically with Aboriginal communities. However, informal consultation and support from Aboriginal community members of the network was ongoing (in keeping with Brunger \& Bull, 2011). This research, like the activism itself, is grounded in an explicit critique of historical relations of power within the region. Constituencies are not represented within the network, but food security issues affect those communities that have

distributed directly from the partnering nonprofit organization to the coordinator. 
been most negatively impacted by a long history of colonialist economic and social policies at various levels of government. Therefore, while the research was not "with" any given Aboriginal community, food security issues are more deeply felt in some communities than others.

Appreciation of the need for ongoing negotiation of the collective risks of research was a key feature of the participant observation research. In particular we paid attention to moments when possible changes to risks and benefits of the research in relation to particular communities might shift whether and how collective consent should take place (as described in Burgess \& Brunger, 2000; F. Brunger \& Weijer, 2007). The authors, through their work with the Labrador Aboriginal Health Research Committee, ${ }^{8}$ are constantly engaged in the process of discussing the

\footnotetext{
8 The Labrador Aboriginal Health Research Committee (LAHRC) is a group composed of representatives of all the Aboriginal communities in Labrador to support research activities designed to assist Labrador Aboriginal communities and organizations in their efforts to promote healing, wellness, and improve health services in their communities. The authors are each invited non-Aboriginal members of the LAHRC.
}

Figure 1. Transportation Map of Labrador

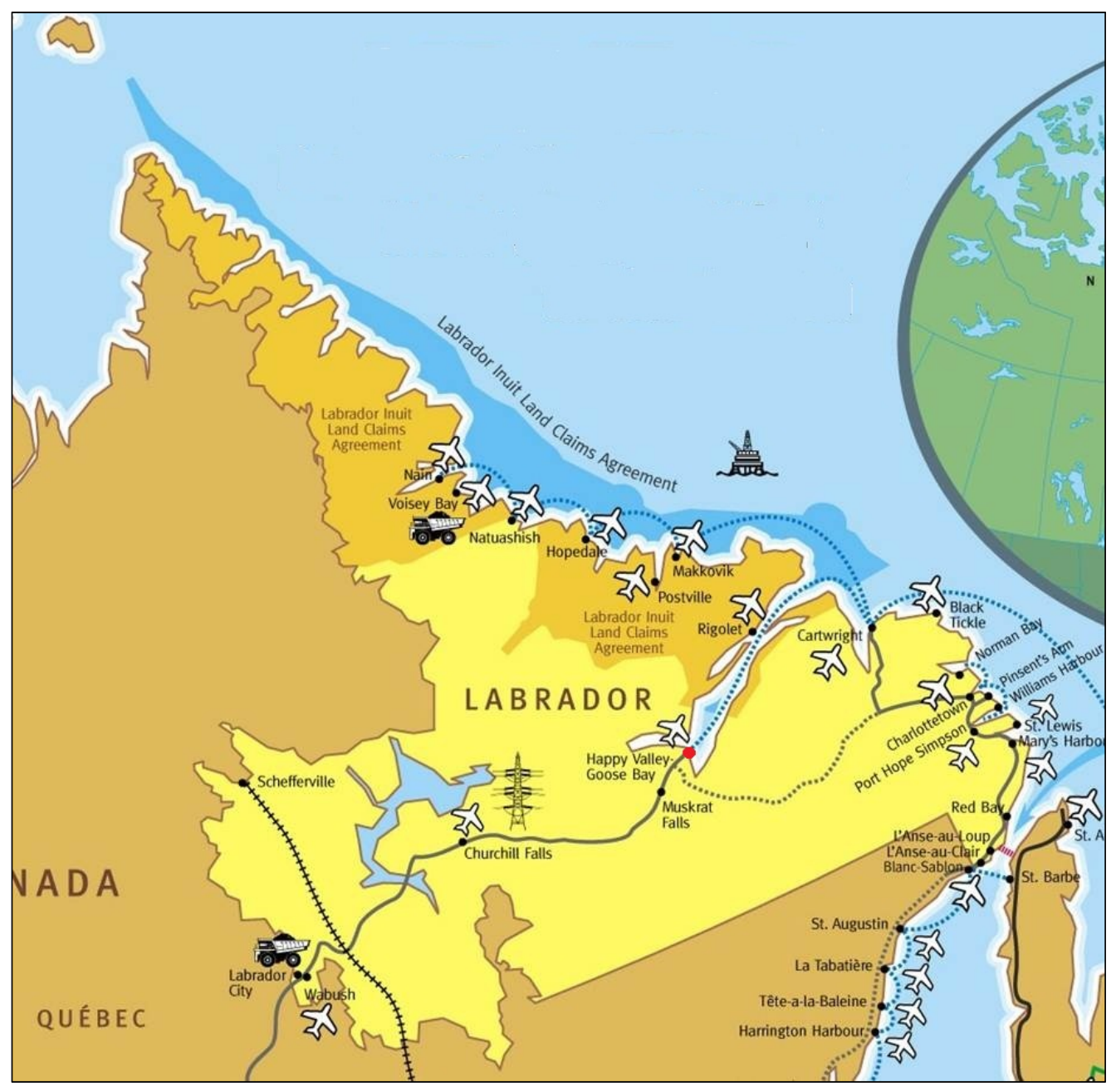

Map provided courtesy of R. Sparkes.

implications of this and other research for Aboriginal communities specifically and generally: There is an explicit understanding that if results implicate particular Aboriginal communities or groups, those results would be discussed with those communities and disseminated with the support of community leadership.

\section{Community Description}

Happy Valley-Goose Bay (HVGB) is a remote, northern town located in the Lake Melville region of central Labrador. With a population of approximately 7,500 , it is the largest community in Labrador and serves as the administrative center for the region. HVGB is the only community with a direct link to all communities in Labrador by sea, 
air, or (unpaved) road. As such, it is a hub for those traveling within Labrador and between Labrador and Canada's major urban centers. Figure 1 illustrates the town's situation within Labrador as a hub for transportation and service delivery.

Due to the town's strategic role as a service center, people from other communities within Labrador come to HVGB for varying periods of time to access services. HVGB is a primary location for residents of Labrador to access health and dental care; make court appearances; visit relatives who are located in the HVGB area; commute to jobsites; access retail and banking services; and access other provincial, federal, and Aboriginal government services. Inuit and many Inuitdescendent communities along Labrador's Atlantic Coast, as well as the Innu First Nation communities of Sheshatshiu and Natuashish, rely on HVGB for essential services. It is a primary location for private- and public-sector regional or headquarter offices, including those of the provincial government, Aboriginal governments (Nunatsiavut government, NunatuKavut Community Council), and Labrador-Grenfell Regional Health Authority.

While many food security issues are generalizable across the North, a diversity of communities and cultures also points to unique issues for individual regions and municipalities. A 2011 report on food security in HVGB details some specific evidence of their effect in the Central Labrador region (Airhart, et al., 2011). The report details high food costs, poor quality of perishable food items, limitations on agricultural production and fishing, and decreased access to country foods as significant limiting factors to food security in the region. These issues are described in more detail below to provide an understanding of the ways in which that community experiences food insecurity. It also provides context for the development of a collaborative entity to address these concerns.

\section{Upper Lake Melville Community Led Food Assessment ${ }^{9}$}

Similar to most other northern and remote communities, HVGB experiences challenges related to

\footnotetext{
${ }^{9}$ This section is based heavily on Airhart et al., 2011.
}

food accessibility, adequacy, and affordability. In 2010 the Food Security Network of Newfoundland and Labrador (FSN-NL), a nonprofit umbrella organization for food security initiatives in the province, received funding from the provincial government to support an investigation of food issues in the Upper Lake Melville ${ }^{10}$ region. A CLFA was conducted during 2010-2011. The yearlong process, which commenced in July 2010, was designed to be a community-driven process, whereby community opinions, priorities, and solutions to food security issues informed the resulting projects. In staying consistent with the values of "community-led" food assessments, a resident of the Lake Melville region who had experience and knowledge regarding food issues was hired as project coordinator. The coordinator was supported by the regional health authority, the FSN-NL, and a local steering committee that was formed to advise and oversee the research. The steering committee was composed of a cross-section of food system representatives, including producers, consumers, and various government and nonprofit agencies. Prior to the CLFA no similar committee, composed of a cross-section of food systems representatives, had ever existed in the region.

The coordinator utilized several types of information-gathering techniques. These included an environmental scan, surveys, focus group discussions, media interviews, and public information sessions, as well as interviews with a diverse range of stakeholders (health workers, dieticians, food producers, food retailers, health promotion workers, school board officials, teachers, college students, parents, clergy, community workers, food bank operators, rural development workers, town council members, fishers and hunters, gardeners, and residents of government housing neighborhoods).

A report was produced on the outcomes of the CLFA (Airhart, et al., 2011). It provides a general overview of the geography of the region as well as

\footnotetext{
10 The Upper Lake Melville region encompasses the communities of HVGB, Mud Lake, Sheshatshiu Innu First Nation, and North West River. HVGB is, by significant measure, the largest of these communities and acts as the service hub for those other small communities in the region.
} 
demographic, economic, and select health indicators for each community and for the region as a whole. This section includes some description of food-related health indicators providing evidence to suggest poor nutrition among residents, high obesity rates, and well above-average prevalence of diabetes. ${ }^{11}$ These findings suggest food insecurity issues similar to those found elsewhere across the North. The report also provides an overview of the food system in the Lake Melville region, including an assets and gaps analysis of the regional food system, a "community action plan," and a process for evaluating implementation of the plan.

There are three primary sections of the report that contribute to an overall description of the regional food system. These sections focus on "the cost of healthy eating"; "community food production"; and "community food access and distribution." The cost of healthy eating section of the report identifies food costs as a primary concern. Although costs are lower than those in more remote communities, retail food prices are still higher than those in "southern" and more accessible regions of Canada. High food costs are identified as especially concerning for those living on low incomes who might have to make choices between paying rent and buying groceries or for parents who skip meals to ensure that their children will have enough to eat.

The report indicates that the Lake Melville region experiences a variety of challenges and strengths related to community food production. Climate, natural soil quality, watershed condition, and availability of land present a variety of barriers. These are further complicated by water and soil quality concerns due to contamination from industrial development and former waste disposal practices at the Goose Bay Canadian Forces Base. Despite the existence of several farms in the area, producers are challenged by environmental conditions as well as government policies that restrict the ability to develop land for agriculture.

\footnotetext{
11 The report provides a detailed and lengthy discussion of food-related health indicators and their impact on individual and community health and well-being.
}

The report also discusses strengths and challenges with regard to fishing and traditional food access. Many Innu, Inuit, and Inuit-Métis residents in the region identify access to country foods and use of traditional hunting and gathering practices as being significant to their physical and emotional health. Primary concerns identified in the report focus on loss of traditional knowledge. These activities are also limited due to issues related to climate change and concerns about environmental contaminants resulting from industrial development activities.

A few challenges are identified in relation to what the report refers to as "community food access and distribution." One of the primary challenges faced by low-income earners is the distance between low-income housing areas and grocery stores. Much of the social (often governmentsupported) housing in the Upper Lake Melville region is not within walking distance of grocery stores, meaning that many residents depend on convenience stores for their food purchases. Another challenge relates to the range of food items available for purchase at grocery stores and other food outlets. The report indicates that freight costs are a limiting factor in the ability of the two major retailers to provide a diverse range of products.

Initial data-gathering techniques for the CLFA were followed by a community-based prioritysetting process. A list of community priorities was compiled based on the information that came from the earlier data collection. Community members were then brought together in various settings to discuss these priorities and to decide which ones they considered most important, which were achievable, and how to implement action plans to address these priorities. The report indicates that six priorities were identified by the community through the research:

1. Development of a community farmers' market;

2. Incorporating food-growing and nutritious food preparation skills into the education system;

3. Creation of community gardens (particularly in low-income neighborhoods); 

4. Supporting and teaching wild food harvest- ing and preserving skills; 5. Increasing community capacity for growing,
preserving, and cooking; and
6. Creating a gleaning and good food box program.

Following identification of these priorities, the report lays out a community food action plan that describes each priority in further detail. An additional priority, "barriers to farming and new farmers," was also added in this section of the report. The action plan also identified inputs, activities, outputs, and expected short- and long-term outcomes for each priority. The report concludes with a process to evaluate implementation of the plan according to key indicators and evaluation methods for each of the expected short- and long-term outcomes.

\section{Lake Melville Food Security Network}

Following the launch of the report, the crosssectoral steering committee that had been formed to oversee the CLFA remained in place to become the Lake Melville Food Security Network and to work on implementation of the priorities. Funding for the CLFA process also extended for several months after the launch of the report so that the CLFA project coordinator was able to stay in a paid position to drive implementation of the priorities. Extension of the paid coordinator into the implementation phase was critical in terms of bridging from research to action, carrying through critical knowledge and relationships built during the CLFA process. During the first year, the food security network was able to fully or partially implement five of the six CLFA priorities.

The first priority, a community farmers' market, was established during the final stages of the CLFA in June 2011, after it had been identified as a top priority. The market grossed CDN\$28,629 in sales during the nine-week period that it ran, with local food producers generating $42 \%$ of the sales and 2,195 participants attending the market over the course of the nine weeks. The market also provided a venue for canning and preserving workshops with community residents, which helped to address the fifth CLFA priority. For the second year of market operation, the food security network received additional funding to expand market hours and include a café. A significant portion of this funding came from government (a crown corporation) and businesses which had been investing in the community in anticipation of an upcoming hydroelectric project in the region.

The second priority, which focused on food growing and nutritious food preparation in schools, also met with immediate success. A children's community garden was established on centrally located town property provided by the municipality of Happy Valley-Goose Bay. Approximately 150 children from the elementary and middle schools took part in the community garden project, where they received instruction on planting seeds, tending the garden, and harvesting. This was followed by a harvest celebration where the children used the produce from their garden to create a nutritious school lunch. The principals of both schools expressed support and enthusiasm for continuation of the project in future years. Funding was secured to build on the project in the second year through incorporation of a greenhouse facility and additional growing stations in the schools. The food security network was also approached by the principal of the middle school to investigate possibilities for nutritious food preparation programs. This resulted in after-school programming involving a variety of food-related workshops in the middle school and expansion to the elementary school.

The third priority, creation of community gardens, also met with success. In addition to the children's garden, in 2012 Newfoundland and Labrador Housing Corporation provided the food security network with a vacant block of land in a low-income area of Happy Valley-Goose Bay. This opportunity was facilitated by the corporation's representative on the food security network. Funding provided through a "Wellness Grant" from the provincial health ministry provided support for involvement of low-income seniors in the garden project. Two community kitchens were established in the same low-income neighborhood, further supporting the fifth priority. The kitchens attracted several hundred participants in the first year. They were run collaboratively by the CLFA coordinator and a Health Canada nutritionist. Operation of the 
kitchens was also supported through food donations from local food retailers and provincial funding from the Newfoundland and Labrador Housing Corporation.

\section{Challenges and Future Directions}

While the network met with considerable success, it experienced a few questions and concerns that are critical to consider when understanding the scope and capacity of its work. A variety of challenges were subsumed by what appeared to be one most significant challenge, which arose only after the network had implemented most of its priorities. This was the broader question of determining what type of organization it wanted to be, based on options available to the group at the time: unincorporated association, incorporated nonprofit, subcommittee of an incorporated organization, or subcommittee of a government department. This question arose primarily due to questions of funding and project implementation. Throughout its existence, the organization had worked to develop project plans and acquire funding, which would then be passed over to another organization that would administer the program or activity. This approach had worked quite successfully and contributed to its success. There was an interest, however, among some members for the network to acquire its own funding and implement projects independently. The network had also run into obstacles, on occasion, where it was unable to avail itself of opportunities or funding due to its inability to identify a suitable and willing incorporated body to take on a particular project.

Despite these obstacles, the network had concerns about changing its status. On one hand, members felt that "joining" an existing organization, in the current governance context, would impact its ability to maintain autonomy and a food systems approach. The network also felt that the reasons for incorporation were not yet strong enough and that, despite the lack of incorporation, it had still been able to maintain a degree of formality and carry out most of its objectives. Ultimately, the network decided to maintain its existing form. It did, however, draft an application for incorporation, including constitution and bylaws, in the case that it ever needed to swiftly incorporate to take advantage of a significant funding opportunity.

Another related challenge was the lack of secure funding for the coordinator position. Concern over stability of funding to ensure paid staff support is common and a primary concern among many food coalitions, networks, and councils (Harper et al., 2009; Schiff, 2007). In this case, the network was fortunate in that the coordinator was a key "champion" of food security initiatives and continued to provide volunteer (unpaid) support through times when there was no funding for a paid position. In the absence of such a champion or in the event that a champion was not able to provide unpaid support, it is doubtful that the network could have implemented as many projects within such a short timeframe. Another fortunate funding circumstance for the network was the presence of a key member representing a nonprofit, community development organization. Through that member's interest in and support of food security initiatives, the network was able to garner in-kind and monetary support that was key in the implementation of several priorities. The network would not have ceased to function without these valuable community champions, but its ability to implement priorities would have been hindered and delayed.

A final challenge related to the ability of the network to engage outside of HVGB, with the broader Upper Lake Melville region. While the CLFA report indicated engagement with the whole of the Upper Lake Melville region, much of the network's initial project activities occurred within the municipal limits of HVGB. Although the network consciously sought opportunities to implement projects in the other communities in the region, few arose outside of the HVGB municipal area. This might have been due to a few factors. Programs in HVGB reached a broad range of Upper Lake Melville residents, reducing the need, for example, to implement a second community market in one of the other communities. There might also have been interest in establishing success in certain programs in HVGB, such as community gardens and food education in schools, before attempting implementation in the region's smaller communities. 
Despite these challenges, the success of the Lake Melville Food Security Network in implementing most of the CLFA priorities within one year is noteworthy. It is the process and factors involved in the success of this collaborative effort that are particularly notable in providing guidance and strategies that might be utilized in other northern or remote regions for building successful CLFA processes and community food security networks.

\section{Lessons Learned:}

\section{Strategies for Success in the Development} of Northern Food Networks

Food systems networks, councils, and working groups often encounter a variety of organizational, procedural, and external factors that can support or hinder success. Many of these factors are documented in existing scholarly literature (Clancy, Hammer, \& Lippoldt, 2007; Dahlberg, 1994; Dahlberg et al., 1997; Hawe \& Stickney, 1997; Lang, Rayner, Rayner, Barling, \& Millstone, 2005; Schiff, 2005, 2007; Webb, Pelletier, Maretzki, \& Wilkins, 1998; Yeatman, 1994, 1997) and reports found in the grey literature (Boron, 2003; Harper et al., 2009). These works are mutually reinforcing and have created a theoretical basis for understanding the ways in which local food councils and networks operate. The experiences of the Lake Melville Food Security Network are particularly noteworthy, however, as they point to additional factors not yet covered in existing literature, particularly with respect to success and the viability of such organizations in northern, remote, and Aboriginal communities.

The experiences of this network warrant attention particularly due to its success with addressing priorities and actions set forth in the community plan. The priorities and action items identified in the plan were not insignificant tasks for a northern community (such as starting a famers' market and school gardening program), yet the group was able to address most priorities within a year of implementation. This is a remarkable feat when compared with the documented experiences of food policy councils, which can struggle for years to gain structure and implement priorities (Schiff, 2007; Yeatman, 1994). It is the processes and factors involved in the success of this collaborative effort that are particularly noteworthy in providing potential guidance and strategies which might be utilized in other northern and remote regions for building successful approaches for food networks, councils, coalitions, or other collaborative efforts for community food security.

The experiences of the Lake Melville Food Security Network point to four critical factors in building capable, resilient, and effective collaborative structures: cross-sectoral membership with private-sector engagement; "tilling the ground"; flexibility and working with opportunity; and utilizing quick wins to build political capital. It should be noted that this analysis posits that all of these factors were critical to the work of this group, and that no factor takes precedence or importance over any other. What follows is a brief description of these approaches and their benefits for building successful collaboratives.

\section{Cross-sectoral membership with \\ private-sector engagement}

The food security network took an intentionally cross-sectoral approach, engaging partners from a multitude of sectors and from various levels of government and nonprofit organizations. The diversity of membership brought through a crosssectoral approach allowed members to learn about an issue, challenges, and potential solutions from a diversity of perspectives, stimulating innovation and new solutions. Engagement across sectors is a common or standard approach in food councils and food networks. What makes the approach of Lake Melville Food Security Network noteworthy is that, although formal membership in the organization was essentially limited to the public sector, there was conscious and targeted engagement with the private sector.

The network formed a variety of partnerships with private-sector interests, two of which are particularly noteworthy. The first was a partnership with the regional economic development board. Although the economic development board was a government-funded nonprofit organization, it provided a bridging role, assisting the network in building partnerships with private-sector entities. 
The other noteworthy approach to private-sector engagement was in direct relationship to major development projects, specifically a major hydroelectric project and renewed interest in uranium exploration in the region. Private-sector entities that were embarking on these major development projects ${ }^{12}$ were searching for opportunities to invest in public welfare and community health. The food security network identified opportunities to utilize this interest to obtain funding, resources, and other forms of support for implementing priorities in community plans. Most importantly, the network was able to take advantage of such resources while maintaining autonomy in its decision-making processes. Engaging with businesses and developers in ways that maintain public ownership and autonomy of the group may be a useful approach for other northern communities undergoing rapid economic growth and experiencing the pressures associated with largescale industrial development.

\section{Tilling the ground through CLFAs}

The CLFA process contributed significantly to the capacity of the food security network to implement its priorities. The activity surrounding the CLFA raised awareness throughout the community and created an environment of heightened interest in food issues, a critical approach in isolated communities where knowledge of the discourses of (community) food security is still limited. Essentially, the CLFA process was "tilling the ground" for the cultivation of partnerships, community concern, understanding of the issues, and investment in solutions. It clearly laid out a variety of community assets, gaps, and priority issues to focus the group's activities. The action plan produced through the CLFA process also allowed for flexibility in how and when priorities would be implemented. The significance of flexibility in plans should not be underestimated: creating definite timelines and structure for interpreting and implementing priorities can lead to disillusionment,

\footnotetext{
12 These entities included, for example, those directly linked to a major hydroelectric project in the region and other major industrial and land developments associated with that project.
}

disengagement, and disbanding of collaboratives when they are unable to meet the exact goals set by a plan.

\section{Flexibility and working with opportunity}

Flexible plans paved the way for another critically useful approach in the context of rapid economic change: working with opportunity. The food security network moulded its activities to adapt to any opportunities as they arose; for example, opportunities for funding, other resources, and current events as opportunities for public outreach and education. The greatest degree of success in this approach came when group members were able to drop an activity that was proving unproductive at a particular point and move on to new opportunities and ideas. A final aspect of the approach involved the willingness and capacity of the groups to encourage, utilize, and celebrate the opportunities presented by "champions" for various initiatives and projects. Yeatman's (1994, 1997) early work on food councils pointed to the significance of champions. The Lake Melville food security network was especially successful with this approach. The group consistently utilized a combination of champions, existing resources, and external opportunities or interest to decide whether to pursue a particular initiative, or store away the idea in the event of future, improved opportunities for implementation.

\section{Quick wins and political capital}

A final aspect of this group's capacity to achieve its goals could be attributed to "quick wins." Although the food security network was not deliberately focused on quick wins, working with opportunity led to the implementation of some immediately successful projects. The group was able to identify projects that could be implemented fairly quickly (due either to relative simplicity or support from an external partner or champion) and that had the potential to draw widespread public attention. An additional benefit of quick wins is their capacity to create broader public support for a collaborative. Allowing private-sector, political, or other external partners to take credit can quickly build valuable political capital. Public and political recognition and support then allows for a shift 
from programmatic to higher-level policy-oriented solutions.

These aspects of success should be considered in the context of the challenges, concerns, and questions the organization faced regarding its status as an unincorporated entity. The capacity to remain flexible and work with opportunity, two critical components of the group's success, might in fact have been facilitated by the organization remaining unincorporated. Concerns over the network's status, however, were significant and should not be minimized. They present a critical area for consideration in the development and growth of northern food networks. Food networks, coalitions, and councils should continue to reflect critically on their own activities, needs, and opportunities, and respond to the unique governance situations presented in their municipalities or local government areas.

\section{Conclusion: Toward Flexible and Collaborative Governance for Northern Food Networks}

Canada's northern and Arctic regions experience high rates of food insecurity, high food costs, environmental concerns related to food shipping and climate change, and a diversity of other challenges related to food production, acquisition, and consumption. Despite the significance of food to healthy development in Canada's north, current governance structures are not able to provide coordinated oversight for changing needs and circumstances. Critical issues associated with food are often fragmented, having little cohesive oversight at municipal, regional, and provincial levels. As such, there is a need for development of governance structures that can provide flexibility to adapt to the changing needs and circumstances of diverse and rapidly changing northern communities.

The experiences of the Lake Melville Food Security Network provide some promising evidence to suggest that collaborative, systems-level approaches can help to address food concerns in northern, remote communities. However, HVGB's role as a service center, and relatively large population base compared to some other northern settlements, suggest that further investigation may be warranted to determine the applicability of such models in smaller, more remote, or non-service center communities. These experiences also point to some approaches to food systems collaboration, as grounded in existing theory on the subject, that might increase capacity to implement solutions for food coalitions across diverse geographies. This research contributes to that existing literature through the addition of information as to how northern and remote communities can utilize community food assessment and food coalition models. In particular, we point to and elaborate on certain factors that might contribute to success and viability of such approaches in northern, remote, and Aboriginal communities. This research suggests approaches for other communities, in particular that collaborative efforts should consider the values of cross-sectoral membership, privatesector engagement, creation of flexible community plans, and utilization of quick wins to build political capital. One of the most productive approaches suggested by this research is for collaboratives to consider working with opportunity. The willingness and capacity of groups to encourage, utilize, and celebrate opportunities and successful outcomes is critical to maintaining a healthy organizational culture and environment for collaboration.

\section{References}

Aboriginal and Northern Affairs Canada. (2008). Regional results of price surveys [Tables]. Retrieved from http://www.aadnc-aandc.gc.ca/eng/ $\underline{1100100035986}$

Airhart, J., Janes, K., \& Jamieson, K. (2011). Food security Upper Lake Melville: Community-led food assessment. St. John's, Newfoundland: Food Security Network of Newfoundland and Labrador.

Beaumier, M., \& Ford, J. D. (2010). Food insecurity among Inuit women exacerbated by socioeconomic stresses and climate change. Canadian Journal of Public Health, 101(3), 196-201.

Boron, S. (2003). Food policy councils: Practice and possibility. Eugene, Oregon: Congressional Hunger Center.

Boult, D. A. (2004). Hunger in the Arctic: Food (in)security in Inuit communities. Ottawa: Ajunnginiq Centre, National Aboriginal Health Organization. Retrieved from http://www.naho.ca/documents/it/ 2004 Inuit Food Security.pdf 
Brunger, F., \& Bull, J. (2011). Whose agenda is it? Regulating health research ethics in Labrador. Études/Inuit/Studies, 35(1-2), 127-142. http://dx.doi.org/10.7202/1012838ar

Burgess, M. M., \& Brunger, F. (2000). Negotiating collective acceptability of health research. In M. McDonald (Ed.), The Governance of Health Research Involving Human Subjects (HRIHS) (pp. 117-151). Ottawa: Law Commission of Canada.

Brunger, F., \& Weijer, C. (2007). Politics, risk, and community in the ICBG-Chiapas case. In J. V. Lavery, E. R. Wahl, C. Grady, \& E. J. Emanuel (Eds.), Ethical issues in international biomedical research: A casebook (pp. 35-42). New York: Oxford University Press.

Canadian Institutes of Health Research [CIHR]. (2008). CIHR Guidelines for health research involving Aboriginal people. Retrieved from http://www.cihrirsc.gc.ca/e/29134.html

CIHR, Natural Sciences and Engineering Research Council of Canada, and Social Sciences and Humanities Research Council of Canada. (2010). Tri-council policy statement: Ethical conduct for research involving humans. Ottawa: Authors.

Chan, H. M., Fediuk, K., Hamilton, S., Rostas, L., Caughey, A., Kuhnlein, H., . . . Loring, E. (2006). Food security in Nunavut, Canada: Barriers and recommendations. International Journal of Circumpolar Health, 65(5). http://dx.doi.org/10.3402/ijch.v65i5.18132

Clancy, K., Hammer, J., \& Lippoldt, D. (2007). Food policy councils: Past, present, and future. In C. C. Hinrichs \& T. A. Lyson (Eds.), Remaking the North American food system. Lincoln, Nebraska: University of Nebraska Press.

Community Food Security Coalition. (n.d.). "Community Food Security Programs: What Do They Look Like? Retrieved from http://www.foodsecurity.org/CFS projects.pdf

Dahlberg, K. A. (1994, June 11). Food policy councils: The experience of five cities and one county. Paper presented at the Joint Meeting of the Agriculture, Food, and Human Values Society, and the Association for the Study of Food and Society, Tuscon, Arizona.

Dahlberg, K. A., Clancy, K., Wilson, R. L., O’Donnell, J., \& Hemingway, T. (1997). Strategies, policy approaches, and resources for local food system planning and organizing: A resource guide. Retrieved from http://homepages.wmich.edu/ dahlberg/

Resource-Guide.html

De Munck, V. C., \& Sobo, E. J. (1998). The forest of methods. In V. C. De Munck (Ed.), Using methods in the field: A practical introduction and casebook (pp. 1337). Walnut Creek, California: AltaMira Press.

Ferguson, H. (2011). Inuit food (in)security in Canada: Assessing the implications and effectiveness of policy. Queen's Policy Review, 2(2), 54-79.

Ford, J., Pearce, T., Smit, B., Wandel, J., Allurut, M., Shappa, K.,...Qrunnut, K. (2007). Reducing vulnerability to climate change in the Arctic: The case of Nunavut, Canada. Arctic, 150-166.

Ford, J. D., Pearce, T., Duerden, F., Furgal, C., \& Smit, B. (2010). Climate change policy responses for Canada's Inuit population: The importance of and opportunities for adaptation. Global Environmental Change, 20(1), 177-191. http://dx.doi.org/10.1016/i.gloenvcha.2009.10.008

Harper, A., Shattuck, A., Holt-Giménez, E., Alkon, A., \& Lambrick, F. (2009). Food policy councils: Lessons learned. Oakland, California: Institute for Food and Development Policy.

Hawe, P., \& Stickney, E. K. (1997). Developing the effectiveness of an intersectoral food policy coalition through formative evaluation. Health Education Research, 12(2), 213-225.

Iacono, J., Brown, A., \& Holtham, C. (2009). Research methods - A case example of participant observation. Electronic Journal of Business Research Methods, 7(1), 39-46.

Jóhannesson, T. (2010). Arctic-Quality certification. Hvanneyri, Iceland: Agricultural University of Iceland. Retrieved from http://www.bioforsk.no/ ikbViewer/Content/75386/Torfi \%20Proposal_ english_revised.pdf

Juday, G. P., Barber, V., Duffy, P., Linderholm, H., Rupp, S., Sparrow, S., . . Wilmking, M. (2010). Agriculture in the Arctic. In I. A. S. Committee (Ed.), Arctic climate impact assessment. Retrieved from the Encyclopedia of the Earth website: http://www.eoearth.org/article/Agriculture in the Arctic

Kawulich, B. B. (2005). Participant observation as a data collection method. Forum: Qualitative Social Research, 6(2). Retrieved from http://www.qualitativeresearch.net/index.php/fqs/article/view/466/ 996Volume 
Ladouceur, L. L., \& Hill, F. (2002). Results of the survey on food quality in six isolated communities in Labrador, March 2001. Ottawa: Indian and Northern Affairs Canada. Retrieved from http://www.aadnc-aandc.gc.ca/ DAM/DAM-INTER-HQ/STAGING/textetext/survfoo2001 1100100035899 eng.pdf

Lang, T., Rayner, G., Rayner, M., Barling, D., \& Millstone, E. (2005). Policy councils on food, nutrition and physical activity: The UK as a case study. Public Health Nutrition, 8(1), 11-19. http://dx.doi.org/10.1079/PHN2004654

Leahey, A. (1954). Soil and agricultural problems in subArctic and Arctic Canada. Arctic, 7(3 \& 4), 249-254.

LeCompte, M. D., \& Schensul, J. J. (2010). Designing and conducting ethnographic research (Vol. 1: Ethnographer's toolkit). Walnut Creek, California: AltaMira Press.

McNiven, C., \& Puderer, H. (2000). Delineation of Canada's North: An Examination of the North-South Relationship in Canada. Ottawa: Statistics Canada.

Meakin, S., \& Kurvits, T. (2009). Assessing the impacts of climate change on food security in the Canadian Arctic. Ottawa: Indian Affairs and Northern Affairs Canada.

Myers, H., Powell, S., \& Duhaime, G. (2004). Setting the table for food security: Policy impacts in Nunavut. Canadian Journal of Native Studies, 24(2), 425-445.

National Aboriginal Health Organisation [NAHO]. (2003). Ethics tool kit: Information to share from the First Nations Centre of the National Aboriginal Health Organization. Ottawa: First Nations Centre of the National Aboriginal Health Organization. Available at: http://www.naho.ca/documents/fnc/english/ FNC EthicsToolkit.pdf

Pothukuchi, K., \& Kaufman, J. L. (1999). Placing the food system on the urban agenda: The role of municipal institutions in food systems planning. Agriculture and Human Values, 16(2), 213-224. http://dx.doi.org/10.1023/A:1007558805953
Pothukuchi, K., \& Kaufman, J. L. (2000). The food system: A stranger to the planning field. Journal of the American Planning Association, 66(2), 113-124. http://dx.doi.org/10.1080/01944360008976093

Schiff, R. (2005, December 1). Public policy and planning for sustainability in the urban food system. Paper presented at the 2nd State of Australian Cities, Brisbane.

Schiff, R. (2007). Food policy councils: An examination of organisational structure, process, and contribution to alternative food movements (Doctoral dissertation). Murdoch University, Murdoch, Australia. Retrieved from http://researchrepository. murdoch.edu.au/293/

Thompson, S. (2005). Sustainability and vulnerability: Aboriginal Arctic food security in a toxic world. In F. Berkes, R. Huebert, H. Fast, M. Manseau \& A. Diduck (Eds.), Breaking ice: Renewable resource and ocean management in the Canadian north (pp. 47-70). Calgary: University of Calgary Press.

Webb, K. L., Pelletier, D., Maretzki, A. N., \& Wilkins, J. (1998). Local food policy coalitions: Evaluation issues as seen by academics, project organizers, and funders. Agriculture and Human Values, 15(1), 65-75. http://dx.doi.org/10.1023/A:1007408901642

Yeatman, H. (1994). Food policy councils in North America - Observations and insights.

Wollongong: University of Wollongong, Australia. http://www.uow.edu.au/content/groups/public/ @,web/@,health/documents/doc/uow025389.pdf

Yeatman, H. (1997). The food system and local government in Australia: The current situation and opportunities for the future. Journal of Nutrition Education, 29(5), 258-266. http://dx.doi.org/10.1016/S0022-3182(97)70215-2

Yeatman, H. (2003). Food and nutrition policy at the local level: Key factors that influence the policy development process. Critical Public Health, 13(2), 125-138. http://dx.doi.org/10.1080/0958159031000097625 